\title{
Serum Testosterone, Luteinizing Hormone and Follicle Stimulating Hormone Concentrations in Mature Sahel Bucks with Dysfunctional Testes
}

\author{
Sule Ayuba Chul*, Saleh Umar Chul**, Mallam Fusami Babagana*** Mohammed Abdullahi Sheikh*, \\ Yunus Haruna*
}

\author{
*Department of Animal Health and Production, Mohamet Lawan College of Agriculture Maiduguri. \\ ** Department of Remedial Science, Ramat Polytechnic Maiduguri \\ ***Dikwa National Biotechnology Development Agency (NABDA)
}

DOI: 10.29322/IJSRP.11.06.2021.p11443

http://dx.doi.org/10.29322/IJSRP.11.06.2021.p11443

\begin{abstract}
This study involved the examination of 2,591 Sahel bucks aged between 2-3 years, out of which 40 were selected. Fifteen of them had full-sized testes while 25 had small-sized testes. Serum concentrations of testosterone, luteinizing hormone (LH) and folliclestimulating hormone (FSH) in these bucks were determined using enzyme-linked immunosorbent assay method. The results revealed that the mean testosterone concentration in bucks with small-sized testes $(0.2 \pm 0.0 \mathrm{iu} / \mathrm{L})$ was significantly $(\mathrm{p}<0.05)$ lower than the mean in the bucks with full-sized testes $(0.7 \pm 0.7 \mathrm{iu} / \mathrm{L}$.). LH concentration in both groups showed no significant ( $>0.05)$ difference. FSH concentration also showed no significant $(\mathrm{p}>0.05)$ difference between the two groups.
\end{abstract}

Index Terms- Follicle stimulating hormone, luteinizing hormone, testicular hypoplasia, testosterone, dysfunctional testes

\section{INTRODUCTION}

$P_{s}$ athological condition of the testis in which the functional capability or performance of testis such as production of spermatozoa and secretion of gonadotropic hormones are compromised is termed dysfunctional testis. Testicular function in terms of hormonal secretion and the size of the testis are directly linked together (Andretta, 1991) and are believed to affect each other directly. Hormones affect testicular size especially during early developmental stage up to the post-pubertal period through unexplained mechanisms that involve physiological effects of hormones on the testis and its surrounding structures (Gomes et al., 1986). Testicular size determines the volume of semen produced (Raji et al., 2008) and semen production depends heavily on gonadotrophins (Delgadillo et al., 1999). Testicular dysfunction manifests itself based on the etiological agent and this in turn affects the reproductive performance of the animal accordingly (Mathew et al.,1978). In many cases, the affected testis is grossly similar to the normal testis in almost every way except their relative reproductive performance (Lino, 1972). However, most of the affected testes tend to be smaller in size. The difference in size is theoretically due to reduction in number, length, or diameter of the tubules or combination of these. In some cases, germ cells may be present but fail to produce spermatozoa or may be totally absent (Rollinson, 1950).

The relevance of dysfunctional testis to goat production is highly significant, this prompted many studies to establish the causes or factors that are linked to this condition among which are: advancing age, chemicals (chemotherapy, halogenated compounds, nitrogencontaining compounds), hormones (dexamethasone, testosterone, zeranolone, estrogen), metal compound toxicity, neoplasia (pituitary tumors, Sertolli cell tumor), nutritional disorders (negative energy balance, fatty acid deficiency, hypovitaminosis A,B,C,E protein and amino acid deficiency and zinc deficiency), plants (Astragalus spp, lysine seeds), radiation, corticosteroid therapy, trauma, ultrasound, viral infection, ochitis (Brucella melitensis) and epididymitis (Corynebacterium pseudotuberclosis). The resultant effects on male reproductive organs include: testicular hypoplasia, testicular degeneration and testicular atrophy (Saab et al., 1997) which may subsequently affect the reproductive performance of the animal. This may be classified as infertility or sub-fertility as a result of testicular dysfunction. These conditions can be unilateral or bilateral depending on the etiology (Bronson, 1989). Testicular hypoplasia is a factor that has been held responsible for at least one-third of all cases of goat infertility (Takebayashiet et al., 1986). It has been reported in goat that testicular hypoplasia is associated with xxy/60, xy karyotype (Padeh et al., 1965). It was hypothesized that testicular hypoplasia may have been associated with an extra $\mathrm{x}$ chromosome. The presence of two cell proportions (xy and xxy) in animals may be explained by at least two mechanisms viz: non disjunction of chromosome $\mathrm{x}$ during the first cell divisions of an xy zygote and formation of $\mathrm{xxy}$ zygote owing to non-disjunction during meiosis followed by the loss of one $\mathrm{x}$ chromosome at the first cell divisions (Madrid et al.,). Infertility in sexually mature animals with small testes is often associated with testicular degeneration and/or testicular hypoplasia (Mentee, 1970). Decrease in scrotal circumference may occur because extremely hot or cold ambient temperature, systemic infections, trauma and nutritional factors (Ott, 1991). It has been shown that lack of adequate levels of follicle-stimulating hormone during 
development delays the attainment of puberty and sporadic successes at mating (Ebling et al., 2002). Follicle-stimulating hormone plays different roles during the male life; it functions as a growth factor during development and sustains spermatogenesis in adults. In mammals, follicle-stimulating hormone has been considered as the main support of gametogenesis in both sexes, while luteinizing hormone is thought to control sex steroid synthesis. Both gonadotrophic hormones play essential roles during the development of male gonadal structures yet with probably significant differences among mammalian species. Luteinizing hormone and testosterone levels regulate each other through the negative feedback mechanism which maintains spermatogenesis (Javier et al., 1986). For an animal to attain puberty, there must be a physiological balance among testosterone, luteinizing hormone and folic-stimulating hormone (Saab et al., 2001).

\section{METHODOLOGY}

Within a period of three weeks in May 2008, the scrotal testes of 2,591 mature Sahel bucks presented for slaughter at the metropolitan abattoir, Maiduguri, Borno State, Nigeria, aged 2-3 years by dentition (Chibuzo and Sivachelvan, 1994), were examined and 40 of them were randomly selected on the basis of their testicular size after visual evaluation. 15 of them had full-sized testes while 25 had smallsized testes. Each of the selected bucks was weighed; blood samples were collected by jugular venipuncture into containers without anticoagulant; and after slaughter, testes where collected. The spermatic codes of each testis was cut off at the vascular cone. The tunica vaginalis covering the testis and epididymis was removed and after separation of the testis and epididymis, each was separately weighed and specimens were fixed in $10 \%$ buffered formalin.

Serum samples were harvested from the clotted blood samples which were used to estimate serum concentrations of reproductive hormones. Serum testosterone, follicle-stimulating hormone and luteinizing hormone were measured by enzyme-linked immunosorbent assay method using reagent kits (BIOTEC Laboratories Ltd, Suffolk UK; www.biotec.com)

Data were summarized as means and standard deviations and means were compared by Students' t-test (Chartfield, 1983)

\section{RESULTS}

Table 1. Comparison of testicular and epididymal sizes by weight measurement in bucks with full and small-sized testes.

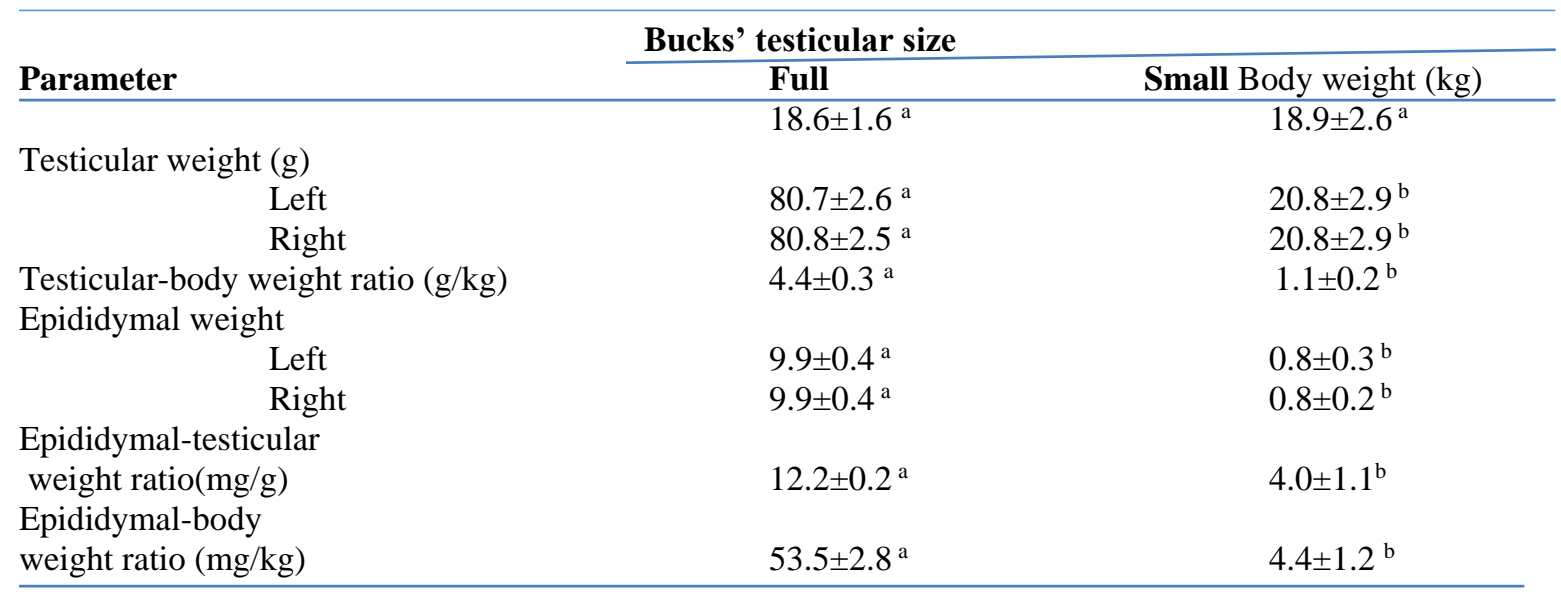

${ }^{\mathrm{a}, \mathrm{b}}$ Means with different superscripts are significantly different $(\mathrm{p}<0.05)$

iu/L- international unit per litre. 
Table 2. Reproductive hormones in Sahel bucks with full and small-sized testes.

\begin{tabular}{llc}
\hline & \multicolumn{2}{c}{ Bucks' testicular size } \\
Serum hormones & Full* & Small* \\
\hline Testosterone (iu/L) & $0.7 \pm 0.7^{\mathrm{a}}$ & $0.2 \pm 0.0^{\mathrm{b}}$ \\
FSH (iu/L) & $1.0 \pm 0.1^{\mathrm{a}}$ & $1.0 \pm 0.2^{\mathrm{a}}$ \\
LH (Iu/L) & $0.5 \pm 0.1^{\mathrm{a}}$ & $0.5 \pm 0.1^{\mathrm{a}}$
\end{tabular}

*Number of bucks was 5 and 15 respectively for full testicular and small testicular size

${ }^{a, b}$ Means with different superscripts are significantly different $(\mathrm{p}<0.05)$

FSH- follicle-stimulating hormone

LH-luteinizing hormone

iu/L- international unit per litre.

The testicular and epididymal measurements in bucks with full-sized and small-sized testes are summarized in table 1 . The left and right testes and epididymes were symmetrical in weights in bucks with full-sized and small-sized testes. The small-sized testes weighed 4 times less than the full-sized testes. This was confirmed with the testicular body weight ratios which were 4:1 in full-sized and smallsized bucks respectively. The small-sized testes had hypoplastic epididymes which weighed lower $(\mathrm{p}<0.05)$ than normal. The normal epididymes in full-sized testes were 12.4 times heavier than the hypoplastic epididymes in small-sized bucks, judging from the mean epididymal weights and epididymal-body weight ratios when the epididymal weights were related to the testicular weights, the epididymal weight was reduced 3 times more than the weight of the testes.

No significant differences occurred in serum follicular-stimulating hormone and luteinizing hormone concentrations in full and smallsized bucks. However, the mean testosterone concentration was significantly $(\mathrm{p}<0.05)$ lower in small-sized than full-sized bucks. All the small-sized bucks had serum testosterone concentrations of $0.2 \mathrm{iu} / \mathrm{L}$, while $60 \%$ of full-sized bucks had serum testosterone concentration of $0.2 \mathrm{iu} / \mathrm{L}$ with the remaining $40 \%$ having $>0.2 \mathrm{iu} / \mathrm{L}$.

\section{References}

[1] Andretta J. R. 1991. Animal Breeding and Reproduction vol. 1. $2^{\text {nd }}$ ed. Cambridge University Press, Cambridge, pp. 560-723.

[2] Gomes N.L., and Vandemark K. The tests vol. 1. Development, Anatomy and Physiology of Small Ruminants. Academic Press New York, pp. 433.

[3] Raji, A.O., Igwebiuke, J.U., Aliyu, J.: Testicular biometry and relationship with body weight of indigenous goats in a semi arid region of Nigeria. ARPN J. Agric. Biol. Sci., 2008; 3: 6-9.

[4] Delgadillo J. A., Canedo G.A., Chameneau P., Cullaume D., Malpous B., 1999. Veterinary Theriogenology. An imprint of Elsevier Science, Philadelphia, Pennsylvania, pp. 27-37.

[5] Mathew, J., Raha, C.K.S.V.: 1978. Studies on testicular hypoplasia in goats. Kerala J. Vet. Sci., 1978; 9: 24-30.

[6] Lino, B.F.: Th e output of spermatozoa in rams. II. Relationship to scrotal circumference, testis weight, and the number of spermatozoa in diff erent parts of the urogenital tract. Aust. J. Biol. Sci., 1972; 25: 359.

[7] Rollinson, D.H.L.: A case of testicular hypoplasia in the goat. Vet. Rec., 1950; 62: 303-304.

[8] Saab S.A., Sleiman F.T., Chemaly I., and Eiskaff R., 1997. American Journal of Small Ruminant Research. 25, 17-22

[9] Bronson F.H. 1989. Mammalian Reproductive Biology. University of Chicago Press, Chicago.

[10] Takebayashi S.S.G., and Jorge W. 1986. Testicular hypoplasia in a horned goat with 61,XXY/60,XY karyotype. Jpn. J. Genet. 61, pp. 177-181.

[11] Padeh B., and Soller M. 1965. An XX/XY hermaphrodite in goat. Journal of Medical Science. I, 1008-1012.

[12] Madrid N., Veeramachanemi D.N.I., ParrettD. F., Vanderwert W., and William L. 1988. Scrotal circumference, seminal characteristics and testicular lesions of yearling Angus bulls. J. Vet Res. 49,579-585.

[13] Mcentee K., (1970). Pathology of Domestic Animals $4^{\text {th }}$ ed. Denver University Press, Denver Colorado. Pp. 235.

[14] Ott R. S.1991. Breading soundness examination of bulls. Department of Veterinary Medicine Urbana, Illinois 61801.

[15] Ebling F.P., Wood R.I., Karsch F.J., Vannerson L.A., Suttie J.M., Bucholtz D.C., and Schall R.E., 2002. Ruminant Reproductive Endocrinology $2^{\text {nd }}$ ed. Sounders Company Ltd, London, pp. 273-277

[16] Javier L.A., and Bell E.TI. 1986. Hormones Assays and their Clinical Application. Fourth edition, Churchill Livingstone, pp. 78-102 
[17] Saab S.A., Chamberland H.M., and Delgadillo J.A., 2001. Reproductive Hormones and Male Gonadal Development, $4^{\text {th }}$ ed. Hampton Press Ltd, Arizona, pp. 192-211.

[18] Chibuzo G.A., and Sivachelvan M.N. 1994. Ruminant Dissection Guide, $1^{\text {st }}$ ed. University of Maiduguri, Maiduguri, pp. 271321.

AUTHORS

Sule Ayuba Chul - DVM, Mohamet Lawan College of Agriculture Maiduguri, Nigeria. ayubac4@gmail.com

Saleh Umar Chul- BSc, MSc, Ramat Polytechnic Maiduguri, Nigeria Umarsaleh540@ gmail.com

Mallam Fusami Babagana - DVM, Dikwa National Biotechnology Development Agency (NABDA) babaganamfusami@gmail.com

Mohammed Abdullahi Sheikh-DVM, Mohamet Lawan College of Agriculture Maiduguri, Nigeria asheikh.am@gmail.com

Yunus Haruna- DVM, Mohamet Lawan College of Agriculture Maiduguri, Nigeria, harunyunus@yahoo.com

Correspondence Author-Sule Ayuba Chul, ayubac4@gmail.com, +2348085227786. 